International Journal of Social Science And Human Research

ISSN(print): 2644-0679, ISSN(online): 2644-0695

Volume 04 Issue 09 September 2021

DOI: $10.47191 / \mathrm{ijsshr} / \mathrm{v} 4-\mathrm{i} 9-43$, Impact factor-5.586

Page No: 2575-2584

\title{
Optimization of the Law against Customer Financing That Performs Default in Leasing Agreements Legal Optimization of Customer Financing That Performs Default in Leasing
}

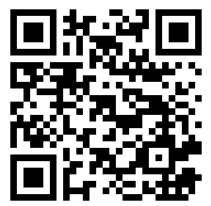
Agreements in Indonesia

\author{
Rianda Dirkareshza ${ }^{1}$, Ratna Sumirat ${ }^{2}$, Risa Gia Anjani ${ }^{3}$ \\ ${ }^{1,2,3}$ Fakultas Hukum, Universitas Pembangunan Nasional Veteran Jakarta, Indonesia
}

\begin{abstract}
There are several facilities provided by financing institutions, until now leasing has become the most frequently used facility by the community. Leasing is a type of fiduciary guarantee, where in the agreement Customer Financing must pay an installment fee against the fiduciary guarantee object until the object can be said to be paid off. In practice, it is often found that Customer Financing defaults with discontinued installments and does not provide voluntary collateral objects to financing institutions. Thus, the dispute of default must be resolved immediately so that it does not take a long time, this financing institution is assisted by a third party, namely debt collectors. However, the passing of Supreme Court Decision No. 18/PUU-XVII/2019 the procedure of execution of the object of bail must now be taken by court process. In addition to the court process is considered relatively long, the value of the object of guarantee also continues to decrease over time, then in this case the financing institution becomes the aggrieved party. Therefore, research is needed so that there is no inequality of rights. This research is conducted with a juridical-normative approach and doctrinal law, with data collection techniques in document studies and leasing staff interviews, and analyzed qualitatively. To increase effectiveness in the implementation of execution rights and avoid losses that are always borne by financing institutions, it requires firm enforcement and optimization of default dispute resolution carried out by Customer Financing.
\end{abstract}

KEYWORDS: Leasing, Fiduciary, Default

\section{INTRODUCTION}

Global economic development forces each country to devise policies that can accelerate the economic growth of a country itself. Leasing has become a popular alternative to buying as a means for consumers to get and use cars, furniture, and other durable goods. (Cooluris, 1982, p. 1184) In financing companies there are forms of multifinance products including leasing, consumer finance, factoring and cash financing. (Yulianti, 2019)

In the Netherlands, the word 'lease' or 'leasing' is an economic term used to denote the presence of certain characteristics in financing arrangements. Generally, leasing is carried out by involving financing institutions (Lessors)who provide capital goods for use by otherparties (CustomerFinancing)in exchange for payment(periodic)or installments given a certain period of time, until the installment can be said to be paid off. (Faber \& Schuijling, 2007, p. 2) Initially in Indonesia, the use of leasing began to be heard in 1974. At first, the leasing facility did not experience encroachment, in 1980 there were only 5 leasing companies, then in 1981 increased to 8 companies, and until the end of 1984 counted as many as 48 companies. This shows a significant increase in leasing facilities, with the growing numberof companies, the increase in the number of leasing contracts running, which is rp. 436.10 billion. Although at that time, leasing in Indonesia was classified as a new institution and there were no laws and regulations that regulated specifically. In fact, until now the regulations on leasing only cover aspects of administrative juridical and tax treatment of leasing businesses in the form of Presidential Decrees and Decrees of the Minister of Finance. (Waode, 2018, p. 748)

This leasing agreement seems to be increasingly popular with the development of industry and trade in Indonesia, in leasing it is said that Customer Financing is the owner of the economy, from the goods he rents, because he gets all the benefits of goods, while the risk of damage or destruction of goods is borne by the Lessor the party that provides financing by leasing to those who need it). In leasing operations, leasing receives goods (means of transportation) including maintenance (service) and in financial leasing, Customer Financing orders its own goods at the cost of the Lessor. In the latter case, usually the cost of maintenance and dependents (insurance) is charged to customer financing. (Waode, 2018) 


\section{Optimization of the Law against Customer Financing That Performs Default in Leasing Agreements Legal Optimization of Customer Financing That Performs Default in Leasing Agreements in Indonesia}

In its implementation, there is an agreement or contract formed between the Lessor and Customer Financing. The contract regarding the installment fee that must be paid by Customer Financing with a certain period of time until the object of the guarantee can be said to be paid off, it can be said to be limited to the sale and purchase transaction if Customer Financing pays the installment. In addition to binding with each other to protect the parties to the risk of the object of guarantee, the contract is also used as a reminder that the object of the guarantee can be repaid in accordance with the period of time contained in the contract or agreement between the Customer Financing party and the Lessor. (Mohamedien, 2002, p. 115)

Although the contract or agreement has been agreed with the signature by both parties, it cannot be denied that it cannot be used as a guarantee for the absence of defaults committed by wrong Customer Financing. In fact, there are often promise injuries made by Customer Financing, the contents of the most commonly violated agreements are installment payments carried out every month or in accordance with the time stated in the contract.

Data recorded in the Ministry of Trade's Consumer Empowerment, in the last three years there were 1,354 cases of disputes, with details of 366 cases in 2017, 571 cases in 2018, and 417 cases in 2019. The data is a dispute that occurs between the financing institution and customer financing. (Hrf/sfr, 2020) From the data, it can be known that the act of promise injury or action against the terms of the contract carried out by the Customer Financing is quite often done. If this happens continuously without observation regarding legal policy updates, then the numbers in the data will continue to increase over time. That a legal policy is needed that contains firmness to Customer Financing regarding sanctions for promise or default injuries that he did and not only the financing institution that always gets additional rules regarding sanctions.

The characterization of the transaction as either an actual "lease" or transaction of such action is likely to have an impact on the rights and remedies that the Lessor allegedly performs in connection with the calculation of indemnity that can be borne based on the document transaction as well as the residual value of the lease object, particularly if Customer Financing files for bankruptcy. (Gross, Liberatore, \& Whelan, 2015, p. 1184) At the outset, leasing) often greatly increases the resources available to businesses that are supposed to rely on equity investments and loans: The Lessor is protected by his or her ownership of the property and therefore does not require payment of the purchase price, the business owner's personal guarantee, mortgage on real business property, or similar arrangements. Peter, 2010, p. 324)

As for examples of moving objects or imovable objects hired to try to be in New York, the Lessor will be faced with many things that must be done. While the trend of state law is clearly far from burdening the Lessor with liability, there are a number of practical solutions that can be applied to reduce the risk of rent for business in New York. Among other things, the Lessor may: (i) terminate consumer collateral liability, (ii) change the rental contract to prevent the use of the vehicle in the state as an unlimited representative liability, (iii) shift the cost of replacement liability to Customer Financing,(iv) require that Customer Financing maintain the statutory mandated level of insurance and implement insurance tracking procedures, (v) transfer ownership rights to leased vehicles, (vi) offer new installment sales contracts, (vii) ensure that lessors do not create an agency relationship with Customer Financing , and (viii) pursue legislative decisions to revoke or change the unlimited representative liability of new laws in New York. (Rojc \& Stendahl, 2004, p. 1177) In this regard, Indonesia can model the policy related to leasing in New York. This intends to be able to optimize the acceleration of the economy in Indonesia.

The Lessor's ability to own an asset is a major benefit of leasing. This ability to have a return allows the Lessor to implicitly provide more credit than lenders whose claims are secured with the same asset. Leasing debt capacity thus exceeds the capacity of guaranteed loan debt. This makes leasing valuable for companies that have financial limitations. (Eisfeldt, Rampini, Eisfeldt, \& Rampini, 2009, p. 1621) However, the Lessor may reject an agreement on an object due to a nonconformity with the contract offer. The rejection is by the Lessor, if he is the buyer/CustomerFinancing. (Breslaauer, 1992, p. 325)

In practice, there are several actions against contracts carried out by Customer Financing, such as late payment of installments and transfer of rights to others without notifying the Lessor in advance. Often this happens due to economic constraints when the leasing contract has taken place. Sometimes the path taken by the Lessor is to do cessie or transfer rights, this is done forcibly to maintain the efficiency of leasingfacilities, both regarding the transfer of installment payments and transfers in the context of buying and selling collateral objects to other parties. This action causes a legal effect, among others, to the leasing agreement made between Customer Financing and The Lessor, legal consequences of the leasingobject, as well as legal consequences concerning the rights of third parties as recipients of such transfers. (Bhudiman, 2016)

The lack of research on leasing agreements that are more in favor of the Lessor inspires researchers to research the theme of the research. In order to dig up information and concrete data about valid data on leasing, the author will conduct an interview at PT. Astra Sedaya Finance. In this regard, the results of this study will be a recommendation to the government regarding a more concise and biased legal policy only protecting the rights of Customer Financing alone, but also still accommodating the rights of the Lessor as a tax contributor and accelerating the wheels of the nation's economy. The formula of the problems in this research is as follows:

1. How is law enforcement against customer financing that does default? 


\section{Optimization of the Law against Customer Financing That Performs Default in Leasing Agreements Legal Optimization of Customer Financing That Performs Default in Leasing Agreements in Indonesia}

2. How to optimize customer financing that performs default?

\section{RESEARCH METHODS}

This scientific work was created using juridical-normative research methods. In his discussion, researchers used an approach that refers to the laws and regulations or positive laws that apply to the Unitary State of the Republic of Indonesia, and uses legal theories and opinions of legal scientists, especially those related to the issues discussed, in this case called the method of doctrinal legal approach. In data collection, the author conducts interviews with sources who are experts in related fields to complete valid data. (Soemitro, 1990, p. 34)

Data collection techniques are carried out by means of documentation studies of secondary data obtained. To complete the data, the author also conducted interviews with several staff of PT. Astra Sedaya Finance, at D.K.I Jakarta headquarters. Primary and secondary data that have been collected are analyzed qualitatively, then presented descriptively-analytical-prescriptively. Conclusion withdrawal techniques are carried out inductively.

\section{RESULTS AND DISCUSSIONS}

State of the art this research is taken from several examples of previous research as a guide or example for research conducted today. Examples taken in the form of journals about Customer Financing That Do Default in Leasing Agreements. One of the journals entitled "Implementation of Legal Protection Against Lessors in Leasing Agreements (Leases For Business)" by Jafar in 2004 at Diponegoro University which stated that the actions that can be taken by Customer Financing in convincing Lessor regarding its eligibility to obtain leasing facilities limited to the completeness of the requirements submitted / examined at the time of the survey by Lessor,the conclusion of existing eligibility only darninistrasi the fulfillment of the conditions of application, in the field of supervision in the leasing agreement was not found because it was never promised, the mechanism of dispute resolution of open and can be on the side of the parties who are the response of balk faith to resolve the problem. (Jafar, 2004)

In the Dissertation by Siti Malikhatun Badriyah which was corrected in 2011, with the title"BreedingOf The Principles of Legal Agreements In Financing Agreements With Capital Goods Objects That Develop In Society (Study of Leasing Agreements In Indonesia)". In his Dissertation concluded that in the practice of leasing agreements there are deviations in the legal principles of the agreement and the principles of leasing so as to cause imbalances; the glorification of the legal principles of the agreement must be done in order for balance to occur; The legal principle of the resulting agreement is the principle of harmony as the principle of prismatic treaty law, which is the integration of the principles of propriety, justice, barrel, harmony, balance, proportionality. (Badriyah, 2011) This research by Siti Badriyah focuses on studying the principles used in leasing agreements.

The Journal published in the Journal of Legal Preference with the title "Legal Protection Against Renting Employers Renting Motor Vehicles Harmed By Consumers In Paul Rental Bike Company Badung Regency" written by Philipus Dian Anjaraka, I Nyoman Putu Budiartha, Luh Putu Suryani who concluded that dispute resolution efforts between business owners, especially motor vehicle rentals when harmed by consumers, were done by non-litigation, using one of the alternatives to out-of-court dispute resolution with mediation and negotiation mechanisms to the tenant who had apologized by returning the money agreed by both parties. In addition, the inhibiting factor in dispute resolution efforts between business owners who are harmed by consumers in the dispute resolution process is a factor of the rule of law. In this case because the loss is classified in the civil domain, it takes time to prove the damages that must be legal from the court. Not only the rule of law, but also the factor of law enforcement processing damages for so long and slowly. (Suryani, Law, Warmadewa, \& Vehicle, 2020, p. 234) In this scientific article emphasizes that the case of loss that befell the Lessor has a slow exit so that the best alternative at this time is to mediate between parties to find the best way out.

Dissertation, Thesis and Journal related to Customer Financing that performs default in leasing agreements so that it can be concluded that the research theme to be raised by the author has a novelty that is different from existing scientific articles. The research topic raised by the author focuses on how to optimize the law against customer financing that defaults in leasing agreements, where the author will seek the best input for the acceleration of legal processes in theprocess of returning rights by the Lessor.

\section{Law enforcement against customer financing that defaults}

Lessor and Lesse are relationships created because of mutual relationships between the parties. The existence of rights and obligations that must be implemented and the creation of legal certainty then the legal obligations are made financial lease agreements or financing agreements with the aim of implementing these rights and obligations. Financial lease agreements give birth to the legal right for the Lessor to sell or confiscate the lease object, if the Lesse performs a default act. (Sunaryo, 2008, p. $1)$.

Broken promises(default)can occur because Lesse neglects to meet his payment obligations, it is an example of a problem between the Lessor and lesse. Lesse can be said to be default if ignoring the contents of the agreement made between the Lessor and Lesse. The agreement made between the Lessor and the Lesse is called the Lease Agreement which contains conditional employment contracts between the parties. The contents of the agreement include: (Silondae \& Fariana, 2010, p. 10) 


\section{Optimization of the Law against Customer Financing That Performs Default in Leasing Agreements Legal Optimization of Customer Financing That Performs Default in Leasing Agreements in Indonesia}

1. Lesse's name and address

2. Type of desired capital goods

3. The amount or value of the goodsleasing

4. Payment terms

5. Terms of ownership or other conditions

6. Fees charged

7. Sanctions if the Buyer /Customer Financing disbelies promise (default)

If all the requirements have been met and agreed, then the Lessor will contact the Supplier or a third party for the negotiation of goods, but in practice even before Lessee apply to the financing company, the Lesse party first negotiates with the supplier, then seeks the financing company as the Lessor party.

In leasing agreements there are suffrage, namely Operating Leasee and Financial Lease. Operating Lease is leasing in business there is no option to buy objects or objects leasing to Customer Financing but only rent and at the end of the contract period Customer Financing can extend the lease or not and the leasing object that at the end of the contract period returns to the Lessor, as the owner and Customer Financing only tenants. While Financial Leasee is the option to buy or rent back the leasing object to Customer Financing remains, staying Customer Financing will buy or keep renting. This is stipulated in the Decree of the Minister of Finance No. 1169/KMK.01/1991 on Leasing Activities in Article 1 letter a, stating that:

"afinancing activity in the form of providing capital goods either on a lease basis with the right of financial lease options or leases without the right of option (operating lease) to be used by Customer Financing for a certain period of time based on periodic financing" (Ministry of Finance of the Republic of Indonesia, 1991)

PT Astra Sedaya Finance or so-called ("PT ASF") is a car and heavy equipment financing company established on July 15 , 1982 located at ACC Building, Jl. Let, Jend TB Simatupang, Kav 90, Tanjung Barat, South Jakarta. In accordance with Financial Services Authority Regulation No. 35/POJK.05/2018 on The Implementation of Financing Company Business, PT ASF has 4 (four) business products in the field of Investment Financing, Working Capital Financing, Multipurpose Financing and Operating Lease, both with conventional and Sharia schemes. (ACC, 2020)

Every activity carried out by PT ASF is loaded and agreed agreements for legal certainty and can run in accordance systematically in accordance with the will of the parties. But not always the agreement goes according to plan because there are times when one of the parties does not carry out its obligations or hurt the promise. (Triwanto, 2019, p. 354) As is the case with the leasing agreement conducted by PT ASF as a Lessor with Customer Financing/Buyer. Often the relationship between The Lessor and Customer Financing is only harmonious at the beginning of the agreement, then the relationship between The Lessor and Customer Financing is tinged with various problems and the main and most often is the delay in fulfilling the obligations of customer financing to the Lessor. Bhudiman, 2016, p. 2)

The non-implementation of Customer Financing/ Buyer obligations aspromised, is an act of default that in the leasing company is a business risk, even not infrequently lessor loses the leasing object. This action is very detrimental to the financing company. So that PT ASF has a customer financingmechanismthat performs default. In a lease-to-business agreement, default may occur if:(Aprilianti, 2015, p. 342)

a. Customer Financing neglects to pay the amount of installment money stipulated in the agreement

b. Customer Financing does not carry out the obligation to pay costs and other costs or late penalties within the specified grace period;

c. Customer Financing has done something prohibited in the agreement, such as transferring rights to others, renting repurpose, pawning the object of the agreement.

In the event that Customer Financing defaults as above, the action taken by PT ASF as a Lessor is to send a message that is a warning letter to Customer Financing as much as $3 \mathrm{x}$ (three times) that Customer Financing must fulfill its obligations by the date set. If after being given a subpoena, the Customer Financing does not also carry out its obligations then the financing company PT ASF provides credit discretion. The policy can be in the form of mediation with Customer Financing whether Customer Financing is having financial problems such as layoffs or other problems. So PT ASF conducts several policies, including:

a. The financing company rescheduling is rescheduling by rescheduling the day or date from the maturity that has been determined in accordance with the renewal agreement, for example, the maturity of July to the maturity of December;

b. Providing an over credit opportunity is the replacement of new debtors who are willing to pay the obligations of old debtors with the approval of financing companies, old debtors, and new debtors;

c. Cessie is the transfer of rights to intangible moving material that is usually in the form of receivables on behalf of a third party, where one sells his rights to others. Third parties as new creditors are entitled to collect debts against debtors and if the debtor defaults, then the new creditor has the right to execute the debtor's objects burdened with guarantees such as mortgages, mortgages, and dependent rights; (Kusumasari, 2011) 


\section{Optimization of the Law against Customer Financing That Performs Default in Leasing Agreements Legal Optimization of Customer Financing That Performs Default in Leasing Agreements in Indonesia}

d. Voluntary settlement(emicable settlement)is the submission of the object of guarantee on the basis of willingness from the debtor.

But if the policy is still ignored by Customer Financing and does not find a solution, then the financing company PT ASF will take or confiscate the goods with the helpof third parties(debtcollectors). Research Team, 2021) In the collection of bad credit carried out by debt collectors is based on the provision of power from the financing company as stipulated in Article 1792 of the Civil Code that:

"Poweris a covenant by which one gives power to another, who receives it, to in the name of carrying out something."

With the understanding of the granting of power of attorney, it states that the granting of power to third parties to collect to Customer Financing who is negligent in paying its debt obligations is legal. This is also regulated in Article 48 paragraph (1) of Financial Services Authority Regulation No. 35/POJK.05/2018 concerning the Implementation of Financing Company Business states that:

"TheFinancing Company may cooperate with other parties to perform billing functions to debtors".

The provisions of cooperation with other parties are regulated in Article 48 paragraph (3) of the Regulation of the Financial Services Authority of the Republic of Indonesia Number 35/POJK.05/2018 which states that:

"Cooperationwith other parties as referred to in paragraph (1) shall fulfill the following provisions:

a. The other party is in the form of a legal entity;

b. The other party has permission from the competent authorities; and

c. The other party has human resources that have obtained certification in the field of billing from the Professional Certification Agency in the field of financing".

Thus, the Financial Services Authority allows financing institutions to use third-party services in debt collection and there is no express prohibition on the use of third party services. If at the time of execution of the leasing object, Customer Financing Debtor is against or not willing to hand over the object or the object is unilaterally transferred to another party then the financing company can report Customer Financing and take the court route..(Research Team, 2021)

Thus, in the event of a dispute there are two ways that can be used to resolve the dispute, namely the parties agree that the dispute will be resolved through deliberation, and if deliberation is not reached, then the parties agree to resolve the dispute in the District Court.

The execution of guarantees against leasing objects is regulated in Law No. 42 of 1999 concerning Fiduciary Guarantees. Republic of Indonesia, 1999) In the Law stipulated that creditors who have received the submission of fiduciary under the Ministry of Law and Human Rights and have obtained a fiduciary certificate, then the execution can be carried out immediately without going through the court because the certificate of fiduciary guarantee has the same executive power as the court's decision as described in Article 15 paragraph (2) of the Fiduciary Guarantee Law. As stated by Soerjono, that the executive power of the fiduciary guarantee certificate gives the right to the fiduciary recipient to be able to execute his fiduciary guarantee on condition that the debtor or fiduciary giver of the promise injury. (Dewi, Saptanti, \& Purwadi, 2017) But it turns out that the meaning arising in Article 15 paragraph (2) is alleged to make fiduciary givers harmed so that on March 24, 2019, the application for material test of Law No. 42 of 1999 to the Constitutional Court, until finally on January 6, 2020 the Constitutional Court decided the application.

In the decree of Mk No. 18 / PUU-XVII / 2019 gives a change in meaning to the sound of Article 15 paragraph (2) and paragraph (3). In its ruling stated that: (Constitutional Court of the Republic of Indonesia, 2019)

1. Declaring Article 15 paragraph (2) of Law No. 42 of 1999 on Fiduciary Guarantee (State Gazette of the Republic of Indonesia of 1999 Number 168, Supplement to State Gazette of the Republic of Indonesia Number 3889) as long as the phrase "executive power" and the phrase "equal to a court ruling of permanent legal force" is contrary to the Constitution of the Republic of Indonesia of 1945 and has no binding legal force as long as it is not interpreted "against the guarantee of fiduciary that does not exist" contrary to the Constitution of the Republic of Indonesia of 1945 and has no binding legal force as long as it is not interpreted "against the guarantee of a permanent fiduciary law" contrary to the Constitution of the Republic of Indonesia of 1945 and has no binding legal force as long as it is not interpreted "against the guarantee of a permanent law" contrary to the Constitution of the Republic of Indonesia of 1945 and has no binding legal force as long as it is not interpreted "against the guarantee of a permanent fiduciary" contrary to the Constitution of the Republic of Indonesia of 1945 and has no binding legal force as long as it does not exist "against the guarantee of a permanent fiduciary" contrary to the Constitution of the Republic of Indonesia of 1945 and has no binding legal force as long as it is not interpreted "against the guarantee of a permanent fiduciary" contrary to the Constitution of the Republic of Indonesia of 1945 and has no agreement on the injury of the promise(default)and the debtor objects to voluntarily submit the object to which the fiduciary guarantee, then all legal mechanisms and procedures in the execution of the Fiduciary Guarantee Certificate must be carried out and apply the same as the execution of a court decision that has permanent legal force"; 


\section{Optimization of the Law against Customer Financing That Performs Default in Leasing Agreements Legal Optimization of Customer Financing That Performs Default in Leasing Agreements in Indonesia}

2. Declaring Article 15 paragraph (3) of Law No. 42 of 1999 on Fiduciary Guarantee (State Gazette of the Republic of Indonesia Of 1999 Number 168, Supplement of State Gazette of the Republic of Indonesia Number 3889) as long as the phrase "promise injury" is contrary to the Constitution of the Republic of Indonesia of 1945 and has no binding legal force as long as it does not mean that "the existence of a promise injury is not determined unilaterally by the creditor but on the basis of an agreement between creditors" with the debtor or on the basis of legal efforts that determine the injury of the promise";

3. $\quad$ Stating the Explanation of Article 15 paragraph (2) of Law No. 42 of 1999 on Fiduciary Guarantee (State Gazette of the Republic of Indonesia Year 1999 Number 168, Supplement to State Gazette of the Republic of Indonesia Number 3889) as long as the phrase "executive power" is contrary to Law 126 of the Constitution of the Republic of Indonesia year 1945 and has no binding legal force as long as it is not interpreted "against the guarantee of a fiduciary that there is no agreement on the injury of promises and debtors object to the agreement of the injury of the promise and debtors objecting to the voluntarily the object that becomes a guarantee of fiduciary, then all legal mechanisms and procedures in the execution of the Fiduciary Guarantee Certificate must be carried out and apply the same as the execution of a court decision that has permanent legal force";

That the meaning of Article 15 paragraph (2) that must first be done an agreement on the injury of the promise(default)between the giver and the recipient ofthe fiduciary, and the fiduciary giver must voluntarily submit the object of fiduciary guarantee, then the execution can be carried out. If these two things cannot be agreed upon by the parties then the execution is carried out in accordance with the provisions of the laws and regulations. Then the meaning of Article 15 paragraph (3) that the injury of the promise(default)must be determined by the agreement of the parties, meaning that the promise injury clause must be discussed in more detail between the parties with the aim of agreeing and understanding each other about the default in the principal agreement and additional agreement (receivable debt agreement and fiduciary guarantee loading deed). The promise injury clause must be set forth in the principal agreement, and the notary in making the fiduciary guarantee deed can ensure that both parties understand the injury of the promise contained in the main agreement. However, if the clause regarding the injury of the promise is unclear and there is no agreement between the parties, it can be done based on legal efforts. Legal efforts must be taken to get legal certainty whether the fiduciary has made a promise injury to the debt receivable agreement between the two parties. (Febriyanti, 2020, pp. 49-50.)

If it is considered by the Constitutional Court Decision No. 18 / PUU-XVII / 2019, if there is a question what if the implementation of the execution of fiduciary guarantees that have agreed to the existence of a promise injury clearly, but the debtor still objects to voluntarily submit the fiduciary object then it can be seen the opinion of the Constitutional Court "The Fiduciary Guarantee Agreement must fulfill the principle of legal certainty and a sense of justice, in the form of a balance of legal rights between the fiduciary rights giver (Debit). your) and fiduciary recipients (Creditors)"(Constitutional Court of the Republic of Indonesia, 2019, p. 121) in line with the consideration of the Constitutional Court, the principle is one of the main reasons for respecting an agreement. The principle of balance is not realized from the equality of the amount of rights and obligations for the parties, but rather to the division of the portion of rights and obligations of greeting an agreement and the implementation of the principle is realized in the form of the formulation of a clause regarding "voluntary submission of objects that are the object of Fiduciary Guarantee" from the Debtor to creditors as a result of the occurrence of the event of an injury(default).

The executory power of the Fiduciary Guarantee Certificate as referred to in Article 15 paragraph (2) of the Fiduciary Guarantee Law, remains binding and the execution is subject to Article 29, Article 30 and Article 31. It bases it on the following considerations:

\section{The Clause/Agreement has fulfilled the Principle of Proportionality}

By formulating the clauses "default"and "voluntary surrender of Objects to which the Fiduciary Guarantee is objected" under the "agreement"/not based solely on "the obligations of any of the parties mentioned in the Fiduciary Law" this has placed the parties in the preparation of the fiduciary guarantee agreement to be in a balanced position, so that the agreement that occurs in such circumstances must be valued in a hustuous position. um, as a binding rule for the parties under Article 1338 of the Civil Code. So that the debtor's objection to voluntarily submit the object that becomes a fiduciary guarantee at the time of the occurrence of "promise/defaultinjury"is no longer relevant to be considered, considering that from the beginning the agreement has fulfilled the principle of legal certainty and a sense of justice, in the form of a balance of legal rights between the fiduciary rights giver (debtor) and the fiduciary (creditor) recipient.

\section{The Clause /Agreement has fulfilled the Principle of Good Faith}

The agreement is a means that brings together the interests of one party with another party actually demands a form of fair and proper exchange of interests that must be carried out in good faith, it is an important point of mind that explains the close correlation between Article 1338 paragraph (3) of the Civil Code and Article 1339 of the Civil Code. The article is the 


\section{Optimization of the Law against Customer Financing That Performs Default in Leasing Agreements Legal Optimization of Customer Financing That Performs Default in Leasing Agreements in Indonesia}

basis of the entry into force of the Principle of Good Faith to all agreements made under Indonesian law, and limits the understanding of the Principle of Freedom of Contract and the Principle of Consensualism. In short, the principle of freedom of contract cannot be interpreted only at the benefit of either party (especially the benefit ofthe party who has been injured by the promise for the difficult surrender of the object), but mustreasonably ensure the fulfillment of the interests of the other party in the implementation of the agreement in accordance with the Principle of Good Faith. Erco Law, 2020)

Thus, the direct execution of leasing objects by financing companies to withdraw fiduciary guarantee objects, against the agreements described above can still be carried out as long as the execution is carried out under Article 29, Article 30 and Article 31 of Law No. 42 of 1999 on Fiduciary Guarantees and is subject to other relevant laws and regulations, including and not limited to Financial Services Authority Regulation No. 35/POJK.05/201 8 on the Company's Financing Business.

\section{Optimization of Customer Financing that defaults}

Lessor as a party in the field of financing companies urgently needs optimization of Customer Financing that defaults on every leasing agreement that occurs. Considering the object promised in a contract is a vehicle. A vehicle is commonly known that every year its value will decrease.

The year of vehicle output will determine the magnitude of the price decline so that it also affects the sales price. In general, the greater the price decrease the year will be smaller. For example, in the first year after the year of car output, the selling price of your vehicle will drop by 10 to 15 percent. In the second year, it will drop by 5 to 10 percent. In the third year, it will fall by 5 to 8 percent, and so on. (Olga, 2019)

The most disadvantaged party in the agreement or contract that has been agreed is the Lessor because if the Lesse defaults then the Lessor is so disadvantaged that even the financing company must issue funds to collect obligations to The Lesse. One of the reasons why the Lessor is so disadvantaged is because the selling value of the object will continue to decrease every year in accordance with the physical condition of the object, then the trial process in Indonesia is quite long. Even the shortest it takes a year. If you look again that the time of one year has caused a decrease in the selling value of the object of the agreement. The government as a regulator on every economic activity in Indonesia should accommodate the needs of the private sector.

Motor vehicle tax is the imposition of taxes that are deducted on the basis of ownership / ownership of motor vehicles paid by the owner every year. Motor vehicle is a two-wheeled vehicle that is energized through the engine and used for land transportation, and mobilized through technical equipment in the form of electric motors and other tools that have the function of converting an energy source to power to drive the vehicle. (Aswati, Mas'ud, \& Nudi, 2018) Motor vehicle tax has benefits for the region, namely: (Kusumawati \& Rachman, 2021)

1. Source of regional income.

2. Fund the implementation of local government

2. For the maintenance and construction of roads and the improvement of facilities

3. public transportation for the community.

4. Can help increase district /city revenue.

5. Useful for improving legal certainty and tranquility for taxpayers.

The government should accommodate the interests of Lessor as a contributor to state taxes in terms of Value Added Tax (VAT) and Income Tax (PPh). When viewed in terms of law enforcement against Customer Financing who break the promise(default)only expect ordinary court proceedings without innovation in it so that it will take a long time until the verdict of the case has permanent legal force (inkracht). When referring to the principle of fast, simple, cost and light justice has been regulated in law No. 48 of 2009 on judicial power that replaces Law No. 4 of 2004 which replaces Law No. 14 of 1970 which in article 4 paragraph 2 states that the judiciary helps justice seekers and seeks to overcome all obstacles and obstacles to the achievement of a simple judiciary, Fast and light cost. (Kaimuddin, 2015, p. 360)

The practice of justice in Indonesia is based on the principle of simple, fast and light costs as outlined in Law No. 48 of 2009 on Judicial Power, the principle is universal which in the courts in Indonesia must uphold the principle. This principle has the meaning of a non-convoluted event, effective time and cost that can be applied to the general public, in practice there are many courts that do not reflect the principle, Robert N. Cole-o Lee Reed argues that the judiciary in resolving disputes often experiences an overcrowded, slow and time-wasting burden, expensive costs and less responsive to the public interest, Or be considered too formal and technical. (Shidiq, Afandi, \& Kaimuddin, 2021, p. 333)

In line with the needs of Lessor who require a simple, fast and light costly judicial process, eating requires innovation to the settlement of special words regarding Customer Financing Actions that default in leasing agreements. This is because it is clear in the contract that contains the rights and obligations of the parties must comply and follow every content of the agreement that has been agreed. But in practice in the field often something different happens when the Lessor collects through a debt collector who is only tasked with collecting the rights that have been promised in the contract. There are several digital traces that occur in 2021, among others: 


\section{Optimization of the Law against Customer Financing That Performs Default in Leasing Agreements Legal Optimization of Customer Financing That Performs Default in Leasing Agreements in Indonesia}

1. "The DC incident was widely discussed by the community and of course the netizens. As a result, 3unit motorcycles thrown into the river suffered quite severe damage. Even some D.C. people were injured." (Ramadan, 2021)

2. "The ganging case occurred because there was an examination of motorcycles owned by residents by debt collectors. The existence of debt collectors at the scene makes residents restless because they often stop motorcycles belonging to passing residents. The herd of debt collectors checked the completeness of the citizens' vehicle papers. so that motorcycle owners and residents carry out attacks on debt collector gathering places." (Juhariyono, 2021)

3. "Allegedly maling, men who work as debt collectors or debt collectors had been shouted at, before desperately plunged into Kali Ciliwung, Gunung Sahari, Central Jakarta." (Lesmana \& Hutasuhut, 2021)

Seeing the number of debt collectors who only carry out duties from the company to become the target of citizen persecution. In fact, the majority of people visited by debt collectors violate the contract of the leasing agreement that has been agreed upon by both parties often do not accept being visited by debt collectors and often they play victims that debt collectors do not have good faith to carry out the execution of leasing objects so that it leads to negative opinions of the public. against debtcollectors. The Constitutional Court confirmed that if Lesse, a delinquent, has admitted to an injury to a promise and voluntarily surrenders the object of his fiduciary agreement, the leasing has full authority to carry out his own execution. (Makki, 2020) But this rarely happens in the community. The government needs to make changes to the judiciary related to the default made by Lesse in leasing cases, the government can model a simple judicial process that does not take a long time. Before the leasing agreement is signed by both parties, customer financing's ability to implement the agreement has been analyzed through credit analysts and ascertained through surveyors. It can be ascertained about the ability of Customer Financing payments to installments, this is only related to the good faith of Customer Financing to carry out payments on time, in case of delays or defaults should only be caused by force major / overmacht.

\section{CONCLUSION}

There is a series of procedures that must be taken by the Lessor first in the process of resolving the default Customer Financing action, namely providing a confirmation warning, providing credit discretion, to confiscate the object of the guarantee with the help of a third party or debt collector. The seizure of the object of the guarantee is based on the executory force as stated in Article 15 paragraph (2) of the Fiduciary Guarantee Law, as well as the implementation of its execution listed in Article 29 , Article 30 and Article 31 of the Fiduciary Guarantee Law and Financial Services Authority Regulation No. 35/ POJK.05/2018 concerning the Implementation of Financing Company Business. In the Constitutional Court Decision No. 18/PUU-XVII/2019 it has been explained that in its implementation, the principle of legal certainty and a sense of justice must be enforced on the division of the portion of rights and obligations between Customer Financing and Lessor in terms of execution of fiduciary guarantee objects.

That when reviewed based on the principle of a quick, simple, cost and light trial that is regulated in Law No. 48 of 2009 on Judicial Power is not in accordance with a series of court procedures that must be taken by the Lessor in the execution of the object of bail. Given the fact that vehicles that are used as collateral objects will always experience depreciation in value and price as the court process progresses. Thus, the government needs to form a short trial that is certainly simpler and does not take a long time. This aims to increase the effectiveness in the execution of the lessor, so that customer financing that has defaulted can be immediately penalized and the lessor does not experience losses on the object of the fiduciary guarantee that has been given.

\section{REFERENCES}

1) ACC. (2020). ACC One. Retrieved June 14, 2021, from acc.co.id website:

https://www.acc.co.id/accone/TentangACC_Detail?Detail=U2FsdGVkX1\%2B0ZfGD\%2FwMpQI6z1b0TOWG\%2FxJxdfyjLhr X2MDbjOD0pcnsEfZSqgpy9yhGZXGac\%2BYHfIA4UMTFZ\%2BDRqo4\%2BQUjFUWKwnHbJJwyxILTelDO9fExtwtY4Zi 8Iy

2) Aprilianti, A. (2015). Perjanjian Sewa Guna Usaha Antara Customer Financing Dan Lessor. FIAT JUSTISIA:Jurnal Ilmu Hukum, 5(3), 315-323.

3) Aswati, W. O., Mas'ud, A., \& Nudi, T. N. (2018). Pengaruh Kesadaran Wajib Pajak, Pengetahuan Pajak, Dan Akuntabilitas Pelayanan Publik Terhadap Kepatuhan Wajib Pajak Kendaraan Bermotor (Studi Kasus Kantor UPTB SAMSAT Kabupaten Muna). Jurnal Akuntansi Dan Keuangan, 3(1), 27-39.

4) Badriyah, S. M. (2011). Pemuliaan (Breeding) Asas-Asas Hukum Perjanjian Dalam Perjanjian Pembiayaan Dengan Objek Barang Modal Yang Berkembang Di Masyarakat (Studi Tentang Perjanjian Leasing Di Indonesia). Tesis.. Universitas Diponegoro.

5) Bhudiman, B. (2016). Perlindungan Hukum Bagi Kreditur Dalam Perjanjian Leasing Pada Pt. Era Cepat Transportindo. Jurnal Yustisi, 3(2), 1-12.

6) Breslauer, P. (1992). Finance Lease Hell or High Water Clause and Third Party Beneficiary Theory in Article 2A of the Uniform Commercial Code. Cornell Law Review, 77(2), 318-349. 
7) Cooluris, J. G. . (1982). Consumer Leasing. American Bar Association, 37(3), 1134-1137.

8) Dewi, R. P., Saptanti, N., \& Purwadi, H. (2017). Kekuatan Eksekutorial Sertifikat Jaminan Fidusia Berdasarkan Undang Undang Nomor 42 Tahun 1999 Tentang Jaminan Fidusia. Jurnal Repertorium Volume, 4(1), 73-81.

9) Eisfeldt, A. L., Rampini, A. A., Eisfeldt, A. L., \& Rampini, A. A. (2009). The Society for Financial Studies Leasing , Ability to Repossess , and Debt Capacity Published by : Oxford University Press. The Review of Financial Studies, 22(4), $1621-1657$.

10) Erco Law. (2020). "Leasing" Masih Bisa Tarik Aset, Anotasi Putusan MK Tentang Fidusia No. 18/PUU-XVII/2019". Retrieved June 14, 2021, from ercolaw.com website: https://ercolaw.com/leasing-masih-bisa-tarik-aset-anotasi-putusan-mk-tentang-fidusiano-18-puu-Xvii-2019/

11) Faber, D., \& Schuijling, B. (2007). Financial Leasing and Its Unification by Unidroit D. Faber \& B. Schuijling. (August 2003), 119.

12) Febriyanti, W. D. R. (2020). Eksekusi Objek Jaminan Fidusia Pasca Putusan Mahkamah Konstitusi Nomor $18 /$ Puu-Xvii/2019. ADHAPER: Jurnal Hukum Acara Perdata, 6(2), 39-52.

13) Gross, E. K., Liberatore, D. A., \& Whelan, S. T. (2015). Lease. The Business Lawyer, 70(4), 1183-1196.

14) Hrf/sfr. (2020). Kemendag Catat 1.354 Sengketa Konsumen Terkait Pembiayaan. Retrieved February 11, 2021, from cnnindonesia website: $\quad$ https://www.cnnindonesia.com/ekonomi/20201027145600-92-563305/kemendag-catat-1354-sengketa-konsumenterkait-pembiayaan

15) Jafar. (2004). Pelaksanaan Perlindungan Hukum Terhadap Lessor Dalam Perjanjian Leasing (Sewa Guna Usaha) (Pascasarjana Universitas Diponegoro). Pascasarjana Universitas Diponegoro.

16) Juhariyono, A. (2021). Polisi Selidiki Kasus Pengeroyokan Debt Collector di Tasikmalaya. Retrieved June 14, 2021, from iNews.id website: https://jabar.inews.id/berita/polisi-selidiki-kasus-pengeroyokan-debt-collector-di-tasikmalaya

17) Kaimuddin, A. (2015). Perlindungan Hukum Korban Tindak Pidana Pencurian Ringan Pada Proses Diversi Tingkat Penyidikan. Arena Hukum, 8(2), 258-279.

18) Kementerian Keuangan Republik Indonesia. Keputusan Menteri Keuangan No. 1169/KMK.01/1991 Tentang Kegiatan Sewa Guna Usaha. , (1991). Jakarta.

19) Kusumasari, D. (2011). Permasalahan Cessie dan Subrogasi. Retrieved June 14, 2021, from hukumonline.com website: https://www.hukumonline.com/klinik/detail/ulasan/cl3400/permasalahan-cessie-dan-subrogasi

20) Kusumawati, I. N., \& Rachman, A. N. (2021). ANALISA PENGARUH WAJIB PAJAK DALAM MEMBAYAR PAJAK. Jurnal Ekonomi-QU, 11(1), 1-20.

21) Lesmana, A. S., \& Hutasuhut, Y. A. A. (2021). Dikejar-kejar Warga, Debt Collector Nekat Terjun ke Kali Ciliwung. Retrieved June 14, 2021, from Suara.com website: https://www.suara.com/news/2021/04/20/134502/ambil-paksa-motor-cewek-awal-debtcollector-dikejar-hingga-nyebur-ke-kali?page=all

22) Mahkamah Konstitusi Republik Indonesia. (2019). Putusan Mahkamah Konstitusi Nomor 18/PUU-XVII/2019. Jakarta.

23) Makki, S. (2020). Leasing Bisa Tarik Kendaraan Kredit Macet Tanpa Pengadilan. Retrieved June 14, 2021, from CNN Indonesia website: https://www.cnnindonesia.com/teknologi/20200114172622-384-465299/leasing-bisa-tarik-kendaraan-kredit-macettanpa-pengadilan

24) Mohamedien, G. W. . (2002). Legal Aspects of Leasing: A Critical Review of Egyptian Law No . 95 of 1995 on Finance Lease. Arab Law Quarterly, 17(95), 108-149.

25) Olga. (2019). Ingin Menjual Mobil Bekas? Pastikan Paham Cara Menentukan Harga! Retrieved June 10, 2021, from Caroline.id website: https://www.caroline.id/berita/cara-menentukan-harga-jual-mobil-bekas/

26) Peter, S. W. (2010). Financial Leasing of Equipment in the Law of the United States. The American Journal of Comparative Law, 58, 323-351.

27) Ramadhan, A. S. (2021). Detik-detik Warga Ngamuk Lempar Motor Milik Debt Collector ke Sungai. Retrieved June 14, 2021, from SuaraJabar.id website: https://jabar.suara.com/read/2021/04/08/151500/detik-detik-warga-ngamuk-lempar-motor-milik-debtcollector-ke-sungai

28) Republik Indonesia. Undang - Undang Nomor 42 Tahun 1999 Tentang Jaminan Fidusia, LN Nomor 168, TLN Nomor 3889. , (1999). Jakarta.

29) Rojc, K., \& Stendahl, K. E. (2004). Vicarious Liability of Motor Vehicle Lessors. American Bar Association, 59(3), $1161-1177$.

30) Shidiq, A. Z., Afandi, \& Kaimuddin, A. (2021). SISTEM E-COURT SEBAGAI WUJUD IMPLEMENTASI ASAS PERADILAN SEDERHANA, CEPAT DAN BIAYA RINGAN. Dinamika Jurnal Ilmiah Ilmu Hukum, 27(3), 331-349.

31) Silondae, A. A., \& Fariana, A. (2010). Aspek Hukum dalam Ekonomi \& Bisnis. Jakarta: Mitra Wacana Media.

32) Soemitro. (1990). Metodologi Penelitian Hukum. Jakarta: Rineka Cipta.

33) Sunaryo. (2008). Hukum Lembaga Pembiayaan (I). Jakarta: Sinar Grafika. 
Optimization of the Law against Customer Financing That Performs Default in Leasing Agreements Legal Optimization of Customer Financing That Performs Default in Leasing Agreements in Indonesia

34) Suryani, L. P., Hukum, F., Warmadewa, U., \& Kendaraan, P. (2020). Perlindungan Hukum Terhadap Pengusaha Sewa Menyewa Kendaraan Bermotor Yang Dirugikan Oleh Konsumen Pada Perusahaan Paulus Rental Bike Kabupaten Badung. 1(1), 234-238.

35) Tim Peneliti. (2021). Wawancara dengan Bapak R. Bagus Dwiantho selaku Corporate Secretary \& Coporate Counsel Division Head PT Astra Sedaya Finance, 20 Mei 2021. Jakarta.

36) Triwanto. (2019). Perlindungan Hukum Konsumen Leasing Terhadap Pencantuman Klausula Baku Dalam Perjanjian Kredit. Jurnal Research Fair Unsri 3, 3(1), 355-364.

37) Waode, D. D. S. (2018). Upaya Hukum Dan Penyelesaian Akibat Default Serta Overmacht Dalam Perjanjian Pembiayaan. Dedikasi Jurnal Mahasiswa, 1(1), 746-749.

38) Yulianti, C. E. (2019). PERLINDUNGAN HUKUM PERUSAHAAN LEASING TERHADAPTERJADINYA PENGGELAPAN OBJEK JAMINAN FIDUSIA. Jurnal Ilmiah Ilmu Hukum Dinamika, 25(1), 1-15. 